\title{
Evaluation of pesticide residues in oranges from São Paulo, Brazil
}

\author{
Viviane Emi NAKANO ${ }^{1 *}$, Tereza Atsuko KUSSUMI ${ }^{1}$, Vera Regina Rossi LEMES ${ }^{1}$, \\ Iracema de Albuquerque KIMURA ${ }^{1}$, Sonia Bio ROCHA ${ }^{1}$, Janete ALABURDA ${ }^{1}$, \\ Maria Celeste Cardeal de OLIVEIRA ${ }^{1}$, Reinaldo Amauri RIBEIRO ${ }^{1}$, Ana Lúcia Rosa FARIA ${ }^{1}$, \\ Kennia Cristian WALDHELM ${ }^{1}$
}

\begin{abstract}
Pesticides in "PERA" orange samples $(N=57)$ from São Paulo City, Brazil were assessed and the pesticide intake contribution was estimated for chronic risk assessment. Seventy-six pesticides were evaluated by the gas chromatography multi-residue method, including isomers and metabolites (4.332 determinations). The mean recoveries at the limit of quantification level were in the range of $72-115 \%$ and the relative standard deviation for five replicate samples was $1-11 \%$. The limits of detection and quantification ranged from 0.005 to $0.4 \mathrm{mg} \cdot \mathrm{kg}^{-1}$ and from 0.01 to $0.8 \mathrm{mg} \cdot \mathrm{kg}^{-1}$, respectively. Pesticides were found in $42.1 \%$ of the samples at levels ranging from 0.06 to $2.9 \mathrm{mg} \cdot \mathrm{kg}^{-1}$. Of the contaminated samples, $3.5 \%$ contained residues (bifenthrin and clofentezine) above the maximum residue level and $12.3 \%$ contained unauthorized pesticides (azinphos-ethyl, parathion, myclobutanil, profenofos, and fenitrothion). The estimated risk characterization for orange intake by adults and children, respectively, ranged from 0.04 to $6.6 \%$ and from 0.1 to $26.5 \%$ of the acceptable daily intake. The detection of irregular residues emphasizes the need for better implementation of Good Agriculture Practices and greater control of formulated products. Other pesticides surveyed did not pose a health risk due to consumption.
\end{abstract}

Keywords: pesticide residues; oranges; public health; risk assessment; chromatography.

Practical Application: Original orange pesticide residue data, estimated health risk to population of São Paulo, Brazil.

\section{Introduction}

Worldwide, farmers use pesticides for protection against crop loss from pests and diseases. The quantity of pesticides and the extent of their use in agriculture have increased rapidly over the past few years (Bempah et al., 2011). Brazil is one of the world's major food producers and is the world's largest pesticide consumer. The pesticide sales increased, by more than 143\% between 2006 and 2013, moving from 204 million to 496 million $\mathrm{kg}$ (Instituto Brasileiro do Meio Ambiente e dos Recursos Naturais Renováveis, 2014).

Improper use of pesticides leads to occupational, environmental and food security risks. Exposure to pesticides has been associated with a wide spectrum of human health hazards, ranging from short-term impacts such as headaches and nausea to chronic diseases like cancer and endocrine disruption. Organophosphate and carbamate pesticides also cause adverse effects in the central nervous system and inhibition of the enzyme acetyl cholinesterase (Chen et al., 2011; United States Environmental Protection Agency, 2014).

The use of pesticides leaves trace amounts of residue on fruits and vegetables. In order to minimize exposure to pesticide residues in food, to protect the health of the population, and to guarantee Good Agriculture Practices (GAP), several countries have established Maximum Residue Levels (MRLs) for pesticides (including isomers and metabolites, collectively termed residues herein) for each crop. Over the past few decades, regulatory authorities in many countries have established systems for monitoring agricultural products and their environmental impact. Pesticide residue monitoring is a tool used to control the quantity of pesticides in food and focuses on the proper use of pesticides in terms of authorization, registration, and compliance with MRLs.

Multiresidues methods have been used to investigate pesticides in food as Mini Luke (The Netherlands, 1996) and QuEChERS (Anastassiades et al., 2003). Gas chromatographs coupled to flame photometric (FPD) and electron capture (ECD) detectors are widely used to quantify pesticide residues. Micro-electron capture detector $(\mu \mathrm{ECD})$ is faster, its results are more reproducible and has lower detection limits than ECD. Furthermore, FPD is a highly selective detector for organophosphorus compounds. FPD and ECD detectors are cheaper and have lower maintenance costs.

In recent decades, the increased demand for food safety has stimulated research related to the risks associated with consumption of fruits and vegetables, which constitute a major part of the human diet and are excellent sources of nutrients and vitamins

${ }^{1}$ Núcleo de Contaminantes Orgânicos, Centro de Contaminantes, Instituto Adolfo Lutz, Coordenadoria de Controle de Doenças, Secretaria de Estado da Saúde de São Paulo, 
(Bempah et al., 2011). The World Health Organization/Food and Agricultural Organization (FAO/WHO) recommend a daily minimum of $400 \mathrm{~g}$ of fruits and vegetables for the prevention of chronic disease such as cancer, diabetes, obesity and heart disease (Food and Agricultural Organization/World Health Organization, 2005). Oranges are among the fruits most widely accepted by consumers, and are thus in high demand in the domestic as well as export markets. Oranges are an excellent source of vitamin C, fiber, and antioxidants (Barros et al., 2012).

Brazil is among the world's largest producers of oranges, accounting for nearly 15 million tons of oranges in 2014, which corresponds to approximately $1 / 3$ of the world production (Instituto Brasileiro de Geografia e Estatística, 2015; Brasil, 2015). Brazilian orange production is concentrated in the state of São Paulo (69\%), with prevalence of the "PERA" orange (Citrus sinensis (L.) Osbeck variety) (Groppo et al., 2009; Instituto Brasileiro de Geografia e Estatística, 2015). São Paulo is the capital city of São Paulo state and it is the largest city in Brazil and South America and exerts strong agribusiness influence. About 20\% of the total crop of oranges is sold as whole fruit; the remainder is used for preparation of orange juice, extracts, and preserves (Food and Agricultural Organization, 2008; Brasil, 2003; Agência Nacional de Vigilância Sanitária, 2012). Given that the orange crop is highly susceptible to pests and diseases, different chemical classes of pesticides are used to treat this crop.

The aim of this study is to analyze pesticide residues in samples of "PERA" oranges from São Paulo City, Brazil, via the multi-residue method and gas chromatography, as well as to perform chronic risk assessment based on the orange intake of the consumer population.

\section{Materials and methods}

\subsection{Sampling}

Samples of "PERA" oranges $(N=57)$ were collected at different commercial sites in São Paulo City (Figure 1) during a period of one and a half years. The collection points included supermarket chains, local markets, grocers, greengrocers, distributors, and retail shops.

The sampling was done according to the requirements of the Codex Alimentarius (1999) for fruits in natura. Each sample batch contained at least 10 units (minimum $2 \mathrm{~kg}$ ). No treatments as removing of peel or washing were applied to samples. All unwashed whole oranges were cut into quarters, homogenized, and ground into slurry. The resulting mixture was immediately analyzed or stored at $-20^{\circ} \mathrm{C}$ until analysis.

\subsection{Analytical method for pesticide residue analysis}

\section{Reagents and chemicals}

High-purity pesticide standards with analysis certificates were purchased from Dr. Ehrenstorfer (Germany) or produced by Riedel de Häen from Sigma Aldrich (United Kingdom). Ultra-residue grade acetone, dichloromethane, and toluene (Mallinckrodt Chemicals, United States), $n$-hexane (J.T. Baker, United States), and isooctane (Merck, Germany) were also used.

Individual standard stock solutions were prepared in isooctane at a concentration of $0.01 \%(\mathrm{~m} / \mathrm{v})$ and stored at $4{ }^{\circ} \mathrm{C}$. Multi-compound standard stock solutions were prepared in $n$-hexane by appropriate dilutions of aliquots from the original stock solution.
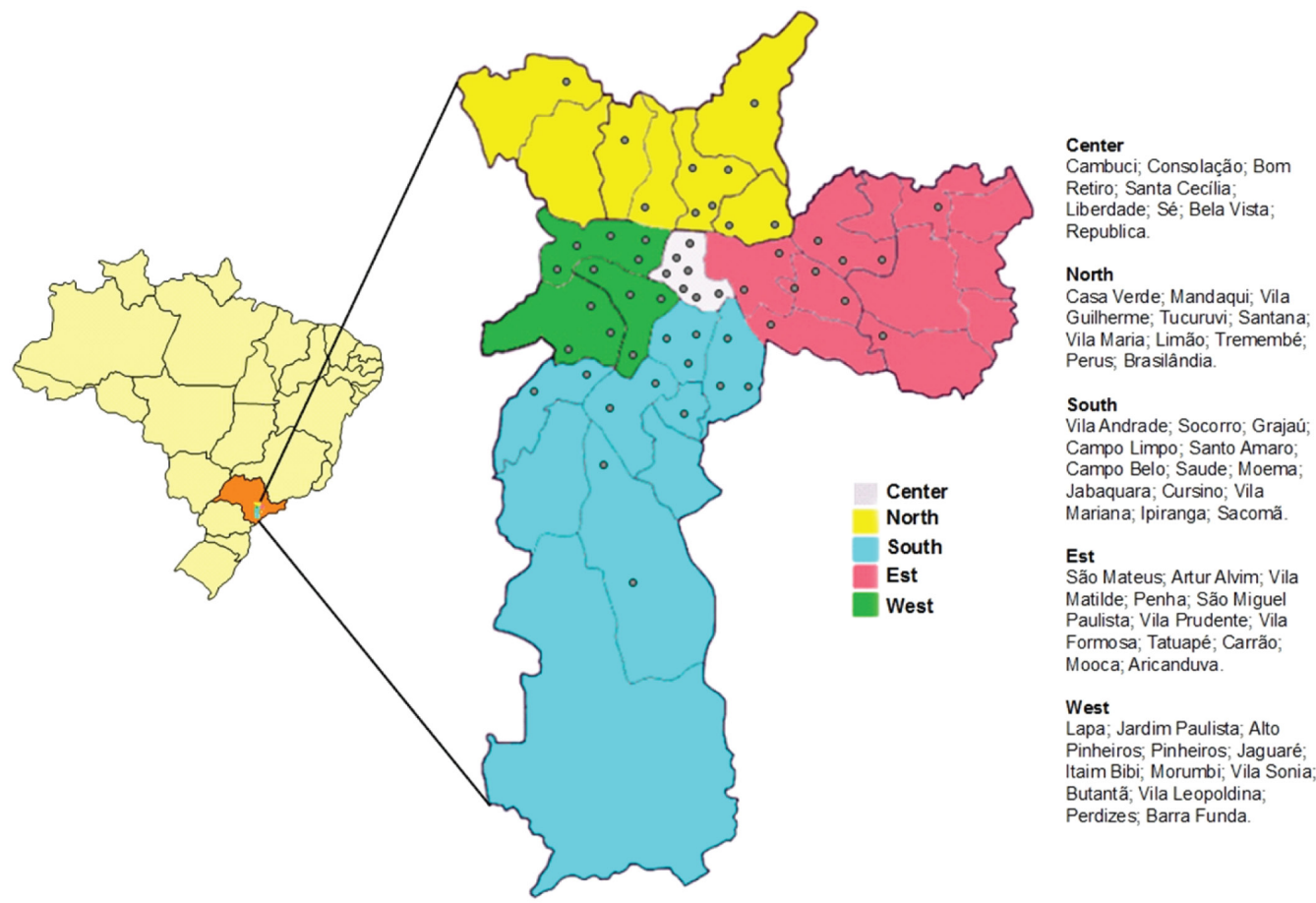

Figure 1. Distribution of sampling sites of "PERA" oranges by region of São Paulo-SP, Brazil. 


\section{Extraction}

The extraction method was based on the Analytical Methods for Pesticide Residues in Foodstuffs, Ministry of Health of the Netherlands with modifications (Toledo et al., 2005).

The previously ground sample ( $30 \mathrm{~g}$ ) was homogenized in an Ultra Turrax mixer with $30 \mathrm{~mL}$ of acetone for $1 \mathrm{~min}$. A mixture of dichloromethane/n-hexane $(1: 1 ; 60 \mathrm{~mL})$ was added and it was again agitated in the Ultra Turrax mixer for $1 \mathrm{~min}$. The mixture was centrifuged and the organic supernatant was used for gas chromatography analyses as described below.

For pesticide residue determination by gas chromatography with a micro-electron capture detector (GC- $\mu \mathrm{ECD}), 2 \mathrm{~mL}$ of the organic extract was filtered through a polytetrafluoroethylene (PTFE) membrane filter ( $0.45 \mu \mathrm{m}$ pore size, $13 \mathrm{~mm}$ diameter $)$ and $0.2 \mathrm{~mL}$ was transferred to a vial and concentrated to almost dryness under nitrogen flow. This residue was dissolved in $n$-hexane to give a final volume of $1 \mathrm{~mL}$ and injected into the GC- $\mu \mathrm{ECD}$.

For analysis of the organophosphorus pesticides, $5 \mathrm{~mL}$ of the organic extract were transferred to a graduated tube and concentrated to almost dryness under a nitrogen stream. A mixture of isooctane/toluene (9:1) was added to produce a final volume of $1 \mathrm{~mL}$, and the sample was injected into the gas chromatograph equipped with a flame photometric detector (GC-FPD), in phosphorus mode.

\section{Chromatographic determination}

Seventy-six compounds of different pesticide chemical classes were investigated and quantified.

Fifty-one pesticide-active ingredients (Table 1) were analyzed using the gas chromatograph equipped with a micro-electron capture detector, Agilent HP6890 GC- $\mu$ ECD. The compounds were

Table 1. Results of GC- $\mu$ ECD analysis of compounds in "PERA" orange samples.

\begin{tabular}{|c|c|c|c|c|c|c|}
\hline Pesticide residues & $\begin{array}{c}\text { Linear working } \\
\text { range } \\
\left(\mathrm{pg} \mu \mathrm{L}^{-1}\right)\end{array}$ & $\begin{array}{c}\mathrm{LOD} \\
\left(\mathrm{mg} \cdot \mathrm{kg}^{-1}\right)\end{array}$ & $\begin{array}{c}\text { LOQ } \\
\left(\mathrm{mg} \cdot \mathrm{k}^{-1}\right)\end{array}$ & $\begin{array}{c}\text { MRL } \\
\left(\mathrm{mg} . \mathrm{kg}^{-1}\right)\end{array}$ & $\begin{array}{c}\text { Total } \\
\text { samples } \\
>\text { LOQ }(\%) \\
\end{array}$ & $\begin{array}{c}\text { Results } \\
\text { min-max } \\
\left(\mathrm{mg} . \mathrm{kg}^{-1}\right) \\
\end{array}$ \\
\hline Alachlor & $0.1-99.5$ & 0.03 & 0.06 & NA & - & ND \\
\hline Aldrin & $0.1-49.5$ & 0.005 & 0.01 & NA & - & ND \\
\hline Allethrin $(1,2)$ & $1.2-118.9$ & 0.1 & 0.2 & NA & - & ND \\
\hline Azoxystrobin & $5.0-83.7$ & 0.2 & 0.4 & 0.5 & - & ND \\
\hline Bifenthrin & $1.0-105.4$ & 0.03 & 0.06 & 0.07 & $2(3.5)$ & $\begin{array}{l}0.06-2.9 \\
1>\mathrm{MRL}\end{array}$ \\
\hline Cyfluthrin $(1,2,3,4)$ & $0.8-80.3$ & 0.2 & 0.4 & NA & - & ND \\
\hline Cypermethrin $(1,2,3,4)$ & $1.4-145.7$ & 0.2 & 0.4 & NA & - & ND \\
\hline Clofentezine & $0.1-49.9$ & 0.05 & 0.1 & 0.2 & $2(3.5)$ & $\begin{array}{r}0.1-0.2 \\
1>\mathrm{MRL}\end{array}$ \\
\hline Chlorfenapyr & $0.1-49.9$ & 0.005 & 0.01 & 0.5 & - & ND \\
\hline Chlorothalonil & $0.2-51.2$ & 0.02 & 0.04 & 0.5 & - & ND \\
\hline DDT (op' and pp' DDD, DDE, DDT) & $0.1-50.0$ & 0.08 & 0.08 & NA & - & ND \\
\hline Deltamethrin & $0.5-79.9$ & 0.02 & 0.04 & 0.1 & - & $\mathrm{ND}$ \\
\hline Dicofol & $0.4-86.3$ & 0.01 & 0.02 & 5 & $2(3.5)$ & 0.06 \\
\hline Dieldrin & $0.1-20.0$ & 0.005 & 0.01 & NA & - & ND \\
\hline Difenoconazole & $10.0-80.6$ & 0.3 & 0.5 & 0.5 & - & ND \\
\hline Endosulfan ( $\alpha, \beta$, and sulfate) & $0.1-50.9$ & 0.01 & 0.03 & NA & - & ND \\
\hline Esfenvalerate (1 and 2 ) & $0.4-78.4$ & 0.1 & 0.2 & 0.05 & - & $\mathrm{ND}$ \\
\hline Fenpropathrin & $0.4-79.6$ & 0.01 & 0.02 & 1 & $1(1.7)$ & 0.1 \\
\hline Fenarimol & $0.6-61.9$ & 0.02 & 0.04 & NA & - & ND \\
\hline Folpet & $1.0-83.9$ & 0.1 & 0.2 & 10 & - & ND \\
\hline $\mathrm{HCB}$ & $0.1-20.2$ & 0.005 & 0.01 & NA & - & ND \\
\hline $\mathrm{HCH}(\alpha, \beta, \gamma$ and $\delta)$ & $0.1-50.6$ & 0.05 & 0.1 & NA & - & ND \\
\hline Heptachlor & $0.2-48.8$ & 0.005 & 0.01 & NA & - & $\mathrm{ND}$ \\
\hline Heptachlor epoxide (cis and trans) & $0.1-54.8$ & 0.01 & 0.02 & NA & - & ND \\
\hline Iprodione & $4.9-78.7$ & 0.2 & 0.4 & NA & - & ND \\
\hline Lambda-cyhalothrin $(1,2)$ & $0.4-81.5$ & 0.1 & 0.2 & 1 & - & ND \\
\hline Myclobutanil & $5.1-82.7$ & 0.2 & 0.4 & NA & $1(1.7)$ & 1.6 \\
\hline Mirex & $0.1-54.4$ & 0.005 & 0.01 & NA & - & ND \\
\hline Oxyfluorfen & $0.1-61.4$ & 0.005 & 0.01 & 0.05 & - & ND \\
\hline Permethrin $(1,2)$ & $1.9-97.3$ & 0.1 & 0.2 & NA & - & ND \\
\hline Procymidone & $0.4-49.9$ & 0.01 & 0.02 & NA & - & ND \\
\hline Propiconazole $(1,2)$ & $4.9-78.4$ & 0.4 & 0.8 & NA & - & $\mathrm{ND}$ \\
\hline Tolylfluanid & $0.3-50.7$ & 0.01 & 0.02 & NA & - & $\mathrm{ND}$ \\
\hline Trifluralin & $0.2-50.7$ & 0.1 & 0.2 & 0.05 & - & ND \\
\hline Vinclozolin & $0.2-49.4$ & 0.005 & 0.01 & NA & - & $\mathrm{ND}$ \\
\hline
\end{tabular}

LOD: limit of detection; LOQ: limit of quantification; MRL: maximum residue level. NA: Non-authorized; ND: Not detected (<LD). 
separated on a 5\%-phenyl/95\%-dimethylsiloxane fused-silica capillary column ( $30 \mathrm{~m}, 0.25 \mathrm{~mm}$ i.d., $0.25 \mu \mathrm{m}$ film thickness). The injector and detector temperatures were set to $250^{\circ} \mathrm{C}$ and $310^{\circ} \mathrm{C}$, respectively. The oven temperature was programmed as follows: $60^{\circ} \mathrm{C}(1 \mathrm{~min}) ; 10^{\circ} \mathrm{C} \cdot \mathrm{min}^{-1} ; 190^{\circ} \mathrm{C}(20 \mathrm{~min}) ; 3^{\circ} \mathrm{C} \cdot \mathrm{min}^{-1}$; $280^{\circ} \mathrm{C}(17 \mathrm{~min}) ; 10^{\circ} \mathrm{C} \cdot \mathrm{min}^{-1} ; 290^{\circ} \mathrm{C}(28 \mathrm{~min})$. Nitrogen was used as a carrier gas at a flow rate of $1 \mathrm{~mL} \cdot \mathrm{min}^{-1}$; an injection volume of $2 \mu \mathrm{L}$ was used in splitless mode. The results were confirmed by using a Thermo Scientific model Trace GC Ultra equipped with an ECD detector and a 35\%-phenyl/65\%-dimethylsiloxane fused-silica capillary column ( $30 \mathrm{~m}, 0.25 \mathrm{~mm}$ i.d., $0.25 \mu \mathrm{m}$ film thickness). The injector and detector temperatures were set to $250{ }^{\circ} \mathrm{C}$ and $310^{\circ} \mathrm{C}$, respectively. The oven temperature was programmed as follows: $60{ }^{\circ} \mathrm{C}(1 \mathrm{~min}) ; 10^{\circ} \mathrm{C} \cdot \mathrm{min}^{-1} ; 220^{\circ} \mathrm{C}$ (6 min); $3^{\circ} \mathrm{C} \cdot \mathrm{min}^{-1} ; 280^{\circ} \mathrm{C}(20 \mathrm{~min})$. Nitrogen was used as the carrier gas at a pressure of $80 \mathrm{Kpa}$; an injection volume of $2 \mu \mathrm{L}$ was used in splitless mode.

Organophosphorus pesticide residue (Table 2) analyses were performed on a gas chromatograph with a flame photometric detector in phosphorus mode (Agilent HP6890 GC-FPD). The compounds were separated on a $14 \%$-phenylcyanopropyl $/ 86 \%$ dimethylsiloxane capillary column ( $30 \mathrm{~m}, 0.25 \mathrm{~mm}$ i.d., $0.25 \mu \mathrm{m}$ film thickness). The injector and detector temperatures were set at $220^{\circ} \mathrm{C}$ and $250{ }^{\circ} \mathrm{C}$, respectively. Two oven temperature programs were used: Program A: $80^{\circ} \mathrm{C}(0 \mathrm{~min}) ; 20^{\circ} \mathrm{C} \cdot \mathrm{min}^{-1}$;
$150{ }^{\circ} \mathrm{C}(30 \mathrm{~min}) ; 5^{\circ} \mathrm{C} \cdot \mathrm{min}^{-1} ; 190^{\circ} \mathrm{C}(0 \mathrm{~min}) ; 10^{\circ} \mathrm{C} \cdot \mathrm{min}^{-1} ; 260^{\circ} \mathrm{C}$ $(10 \mathrm{~min})$ and Program B for results confirmation: $80^{\circ} \mathrm{C}(0 \mathrm{~min})$; $20^{\circ} \mathrm{C} \cdot \mathrm{min}^{-1} ; 140^{\circ} \mathrm{C}(0 \mathrm{~min}) ; 2^{\circ} \mathrm{C} . \mathrm{min}^{-1} ; 190^{\circ} \mathrm{C}(0 \mathrm{~min}) ; 10^{\circ} \mathrm{C}$. $\min ^{-1} ; 260^{\circ} \mathrm{C}(10 \mathrm{~min})$. Nitrogen was used as a carrier gas at pressure of $80 \mathrm{kPA}$ and an injection volume of $2 \mu \mathrm{L}$ was used in splitless mode.

\section{Method evaluation}

The method was previously evaluated under the same conditions using five replicate analyses at levels of 1 limit of quantification (LOQ). The evaluation criteria for the validation parameters used herein are described by the European Commission (European Commission, 2013).

The selectivity was evaluated by comparison with five replicate analyses of blank orange samples from organic production.

Quantification of the pesticide residues was performed by external standardization with calibration curves for each active ingredient, within the linear range of the detector (Tables 1 and 2).

The limit of detection (LOD) and LOQ were determined from the measured value obtained for the matrix blank samples, plus three and six times the standard deviation from replicates of the recovery results analyzed at the LOQ level (European Commission, 2013).

Table 2. Results of GC-FPD analysis of compounds in "PERA" orange samples.

\begin{tabular}{|c|c|c|c|c|c|c|}
\hline Pesticide residues & $\begin{array}{c}\text { Linear } \\
\text { working range } \\
\operatorname{pg} \mu \mathrm{L}^{-1}\end{array}$ & $\begin{array}{l}\text { LOD } \\
\text { mg. kg-1 }\end{array}$ & $\begin{array}{c}\text { LOQ } \\
\text { mg. } \mathrm{kg}^{-1}\end{array}$ & $\begin{array}{c}\text { MRL } \\
\text { mg. kg-1 }\end{array}$ & $\begin{array}{c}\text { Total samples } \\
>\text { LOQ } \\
(\%)\end{array}$ & $\begin{array}{c}\text { Results } \\
\text { min-max } \\
\text { mg. kg-1 }\end{array}$ \\
\hline Azinphos-ethyl & $20.0-2000$ & 0.03 & 0.1 & NA & $1(1.7)$ & 0.2 \\
\hline Carbophenothion & $10.0-1000$ & 0.02 & 0.05 & $\mathrm{NA}$ & - & ND \\
\hline Chlorpyrifos & $22.1-2218$ & 0.03 & 0.1 & 2 & $8(14.0)$ & $0.1-0.5$ \\
\hline Chlorpyrifos-methyl & $41.5-4152$ & 0.03 & 0.1 & NA & - & ND \\
\hline Diazinon & $54.1-2708$ & 0.10 & 0.2 & 0.7 & - & ND \\
\hline Dichlorvos & $23.9-1196$ & 0.03 & 0.1 & NA & - & ND \\
\hline Dimethoate & $22.9-2296$ & 0.03 & 0.1 & 2 & $4(7.0)$ & $0.1-0.2$ \\
\hline Disulfoton & $40.6-2030$ & 0.05 & 0.1 & NA & - & ND \\
\hline Ethoprophos & $30.1-1507$ & 0.05 & 0.1 & NA & - & ND \\
\hline Fenamiphos & $31.4-3146$ & 0.05 & 0.1 & NA & - & ND \\
\hline Fenitrothion & $26.5-2658$ & 0.03 & 0.1 & NA & $3(5.3)$ & $0.1-0.3$ \\
\hline Fenthion & $20.5-2058$ & 0.03 & 0.1 & 0.5 & - & ND \\
\hline Malaoxon & $20.3-2038$ & 0.03 & 0.1 & $\mathrm{NE}$ & - & ND \\
\hline Malathion & $40.2-4020$ & 0.03 & 0.1 & 4 & - & ND \\
\hline Paraoxon-ethyl & $27.7-2770$ & 0.03 & 0.1 & $\mathrm{NA}$ & - & ND \\
\hline Parathion & $21.7-2178$ & 0.03 & 0.1 & NA & $1(1.7)$ & 1.3 \\
\hline Parathion-methyl & $22.6-2266$ & 0.03 & 0.1 & NA & - & $\mathrm{D}$ \\
\hline Phenthoate & $21.2-2126$ & 0.03 & 0.1 & NA & - & ND \\
\hline Phorate & $63.4-3172$ & 0.10 & 0.2 & NA & - & ND \\
\hline Pirimiphos-ethyl & $20.0-2000$ & 0.03 & 0.1 & NA & - & ND \\
\hline Pirimiphos-methyl & $21.7-2178$ & 0.03 & 0.1 & 5.0 & - & $\mathrm{D}$ \\
\hline Profenofos & $28.5-2856$ & 0.03 & 0.1 & NA & $2(3.5)$ & $0.1-1.1$ \\
\hline Prothiofos & $15.4-542$ & 0.01 & 0.05 & 0.01 & - & ND \\
\hline Pyrazophos & $20.0-2000$ & 0.03 & 0.1 & NA & - & ND \\
\hline Vamidathion & $239.6-2396$ & 0.3 & 0.5 & $\mathrm{NA}$ & - & ND \\
\hline
\end{tabular}

LOD: Limit of Detection; LOQ: Limit of Quantification; MRL: Maximum Residue Level. NA: Non-Authorized; NE: Not Established; D: Detected (LOD<D<LOQ) and ND: Not Detected $(<\mathrm{LOD})$. 


\subsection{Intake contribution for chronic risk assessment}

The estimated chronic risk from intake of pesticide residues in oranges was assessed for adult (60 kg body weight, bw) and child ( $15 \mathrm{~kg} \mathrm{bw})$ populations based on the mean or the highest experimental results of each active pesticide component (Table 1 and 2) by employing the estimated Average Daily Annual Consumption of $4.404 \mathrm{~kg}$ orange $/$ person/year from the national data documented by the Instituto Brasileiro de Geografia e Estatística (2010) and the respective Acceptable Daily Intake (ADI) values (Agência Nacional de Vigilância Sanitária, 2012; European Commission, 2009). The results are expressed as percentages (Table 3) based on the Equation 1.

$\mathrm{ER}(\%)=(((\mathrm{PR} \times \mathrm{ADC}) / \mathrm{bw}) \times 100) / \mathrm{ADI}$

where:

$\mathrm{ER}=$ Estimated chronic risk assessment of pesticide residues from orange intake

$\mathrm{PR}=$ the mean or the highest pesticide residue results found (mg.kg $\left.{ }^{-1}\right)$ (Tables 1 and 2)

$\mathrm{ADC}=$ Average Daily Consumption of Orange (g/person/day)

$\mathrm{BW}=$ Body weight $(\mathrm{kg})$

ADI = Acceptable Daily Intake ( $\mu \mathrm{g} / \mathrm{kg}$ bw/day)

To calculate the mean values, pesticide residue results below the LOQ of the method were considered as $0.5 \mathrm{LOQ}$.

\section{Results and discussion}

The results of GC- $\mu \mathrm{ECD}$ and GC-FPD analysis of pesticide residues in the orange samples are presented in Tables 1 and 2, respectively. Seventy-six compounds of different pesticide chemical classes were investigated and quantified, with 4,332 determinations, including isomers and metabolites.

After optimization of the analytical conditions for determination of the pesticide residues, the following parameters were investigated according to the criteria for validation parameters described by the European Commission: working linear range, selectivity, accuracy, precision, LOD and LOQ.

The recovery results ranged from $72 \%$ to $115 \%$ and the precision based on the relative standard deviations (RSD) ranged from $1 \%$ to $11 \%$, under replicated conditions; these values are considered acceptable according to the requirements of the European Commission (2013). The LOD and LOQ ranged from 0.005 to $0.4 \mathrm{mg} \cdot \mathrm{kg}^{-1}$ and 0.01 to $0.8 \mathrm{mg} . \mathrm{kg}^{-1}$, respectively. No residues were detected in the blank orange samples at the LOD of method.

Pesticides were detected in $24(42.1 \%)$ of the orange samples at levels from 0.06 to $2.9 \mathrm{mg} . \mathrm{kg}^{-1}$. One pesticide residue was detected in 21 samples and two residues were simultaneously detected in 3 samples.

These results indicate that systemic pesticides, such as bifenthrin, clofentezine, dicofol, dimethoate, azinphos-ethyl, chlorpyrifos, fenitrothion, parathion, and profenofos were used in treatment of the orange specimens (Tables 1 and 2). The continued use of pesticides may lead to the development of resistant pest species, and studies have shown resistance to the main pest acaricides applied to citrus crops (Campos \& Omoto, 2002). Dicofol resistance was detected throughout the citrus industry about 10 years ago because of the continuous use of this pesticide (Rogers \& Dewdney, 2012).

Dimethoate, fenpropathrin, dicofol, and chlorpyrifos residues were detected, but the concentrations were all below

Table 3. Estimative chronic risk assessment for children and adult population of São Paulo City due to orange intake.

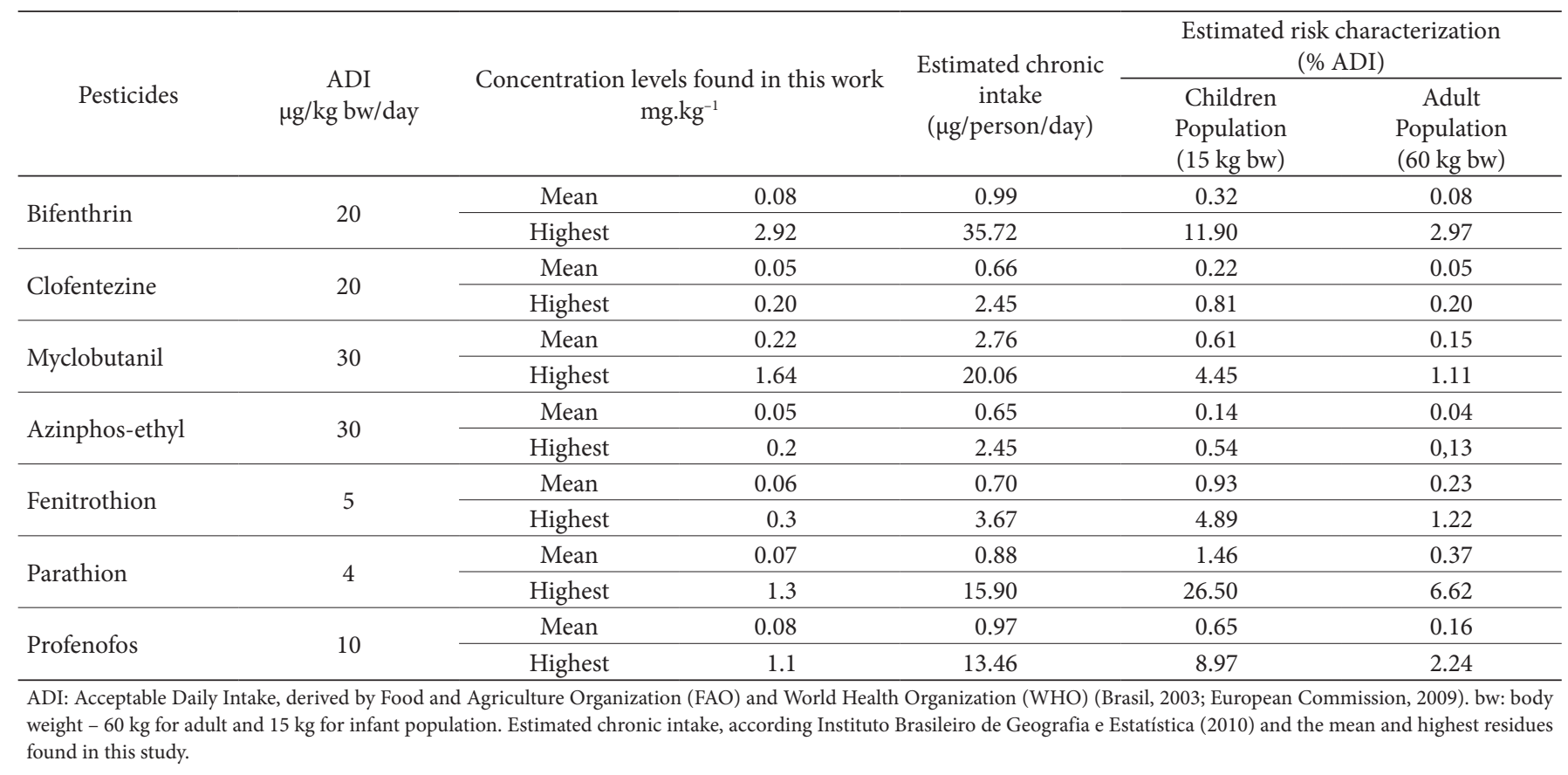


the respective MRLs established in Brazil. Fenpropathrin and dicofol are classified as toxicity class II chemicals and its residues were detected in a study by the Brazilian Health Surveillance Agency/Food Pesticide Residues Analysis Program (Agência Nacional de Vigilância Sanitária, 2009) $(N=147)$ and 2007 $(N=149)$, all below the respective Brazilian MRLs Agência Nacional de Vigilância Sanitária (2010, 2008).

Among the pesticide residues detected herein, chlorpyrifos was most commonly detected (Table 2). It was found in $8(14 \%)$ samples at levels ranging from 0.1 to $0.5 \mathrm{mg} \cdot \mathrm{kg}^{-1}$, all within the MRL established in Brazil. Chlorpyrifos is an organophosphorus insecticide and acaricide that is widely used to combat plagues affecting citrus fruits. These results are consistent with those reported by the ANVISA/PARA program (Agência Nacional de Vigilância Sanitária, 2008, 2009, 2010, 2011) for orange samples collected in other states of Brazil from 2001 to 2010, in which this pesticide was the main compound detected $(7.8 \%$ of the food samples) (Jardim \& Caldas, 2012). Between 2002 and 2005, Gebara et al. (2008) analyzed oranges and other fruits under the Residue Monitoring Program of the São Paulo Distribution Centre (General Storage and Wholesale Commercialization Centre - CEAGESP) and also detected chlorpyrifos among the more frequently found residues (5.2\% of fruit samples). Similar results were reported for samples analyzed in Europe (7.9\% of fruits and vegetables) (European Food Safety Authority, 2010). This compound was also the most frequently detected residue ( $4.8 \%$ of orange samples) in the Denmark Pesticide Food Monitoring program where samples were assayed in 2004 and 2007 (Jensen et al., 2009). Chlorpyrifos was found in 106 (23.4\%) blood-orange samples studied in Italy (Fallico et al., 2009). In another study, it was the most common residue, found in $16.9 \%$ of samples of food from South America exported to Europe Nordic countries including Estonia (Hjorth et al., 2011).

As shown in Tables 1 and 2, two of the present samples (3.5\%) contained residues above or at the MRL levels (bifenthrin and clofentezine) and 8 (14\%) contained unauthorized pesticides (azinphos-ethyl, fenitrothion, parathion, profenofos, and myclobutanil). Biphentrin is classified as toxicity class II, and clofentezine as toxicity class III. The fungicide myclobutanil is not authorized for use in citrus fruits since, it is toxicity class I (extremely toxic) pesticide (Agência Nacional de Vigilância Sanitária, 2012).

Organophosphorus pesticide residues were found in 19 (33\%) samples and $7(12 \%)$ contained non-authorized pesticide residues for citrus (Table 2). Organophosphorus pesticides are inhibitors of the normal action of the enzyme acetyl cholinesterase and are widely used (Fallico et al., 2009). Azinphos-ethyl and parathion are classified as toxicity class I chemicals, while profenofos and fenitrotion are classified as toxicity class II - highly toxic (Agência Nacional de Vigilância Sanitária, 2012) chemicals. Azinphos-ethyl and parathion pesticides are banned from the Brazilian market and parathion is banned also in other countries. Fenitrothion is under toxicological review (Agência Nacional de Vigilância Sanitária, 2012).

Profenofos, myclobutanil, parathion-methyl, and other non-authorized pesticides for citrus were also found during the ANVISA/PARA program. In the results obtained in 2008, irregularities were detected in $14.8 \%$ of the 101 analyzed orange samples due the presence of triazophos residues above the MRL in one sample, and the presence of non-authorized pesticides, such as endosulfan and parathion-methyl $(N=1)$, profenofos $(N=2)$, prochloraz $(N=3)$, and cypermethrin $(N=9)$ (Agência Nacional de Vigilância Sanitária, 2009) in the others. Furthermore, of the 146 orange samples analyzed in 2009 , irregularities were found in $10.3 \%$, where $9.6 \%$ contained non-authorized pesticides, such as carbaryl, endosulfan, and permethrin $(N=1)$, prochloraz $(N=4)$, and cypermethrin $(N=7)$ and $0.7 \%$ presented triazophos residues above the MRL (Agência Nacional de Vigilância Sanitária, 2010). In 2010, 148 orange samples were monitored and irregularities were detected in $12.2 \%$, as $2 \%$ contained pesticide residue levels above the MRL and $10.1 \%$ contained non-authorized pesticides, such as parathion-methyl, profenofos, beta-cypermethrin, cyproconazole, malaoxon, methomyl, and permethrin $(N=1)$ and prochloraz $(N=6)$ (Agência Nacional de Vigilância Sanitária, 2011). In 2012, 227 orange samples were monitored and $28 \%$ were inadequate, where $26 \%$ contained non-authorized pesticides and 3\% presented pesticide residue levels above the MRL (Agência Nacional de Vigilância Sanitária, 2013). Profenofos was found in one orange sample at a level of $0.01 \mathrm{mg} \cdot \mathrm{kg}^{-1}$ and myclobutanil was detected in 14 samples (LOD: $0.002 \mathrm{mg} \cdot \mathrm{kg}^{-1}$ ), among other residues (Agência Nacional de Vigilância Sanitária, 2013).

No endosulfan residues were detected in the oranges analyzed in this study; however, such residues were found in other food samples analyzed by ANVISA/PARA in $2008(N=1)$, $2009(N=1)$, and $2010(N=5)$ (Agência Nacional de Vigilância Sanitária, 2009, 2010, 2011). These and other banned pesticides have been found in food samples from various Brazilian states, contributing to increased dietary risk to consumers. According ANVISA (Brasil, 2014), the monograph of the active ingredient endossulfan was cancelled.

The pesticide residues analyzed in this study have been evaluated in previous studies of whole oranges (Chen et al., 2011; Parveen et al., 2011; Knezevic et al., 2012; Torres et al., 1996; Jardim \& Caldas, 2012; Neff et al., 2012; Farag et al., 2011; Fallico et al., 2009; Hjorth et al., 2011) and orange juice (Iñigo-Nuñez et al., 2010).

Fallico et al. analyzed 24 pesticides in 460 samples of Italian Tarocco oranges from 2003 to 2007. Compared with the compounds investigated in this work, that study recorded the presence of chlorpyrifos-ethyl (23\%), chlorpyrifos-methyl (8\%), dicofol (0.7\%), fenitrothion (0.9\%), and malathion (0.4\%) among other pesticides (Fallico et al., 2009).

Chen et al. (2011) analyzed 22 pesticides residues in 13 orange samples collected from October 2006 to March 2009 at randomly selected wholesalers or large supermarkets from Xiamen City, China. No pesticide residues were detected in these samples.

From 2008 to 2009, Parveen et al. (2011) investigated 10 citrus samples from different selling points of Karachi, Pakistan; $70 \%$ of them presented residues. Fourteen pesticides similar to those of the present study were surveyed, and the results also indicated the presence of bifenthrin $(N=3)$, fenitrothion $(N=1)$, and dimethoate $(N=1)$ below the MRLs; from among 
the unauthorized pesticides in Brazil, malathion, cipermethrin, deltamethrin, and permethrin were not detected.

Iñigo-Nuñez et al. (2010) evaluated 65 pesticides in 19 orange juice samples from markets in Madrid (Spain). Compared with the compounds studied in this research, two organophosphorus pesticides were found, chlorpyrifos (5.3\%) and diazinon (10.5\%).

Farag et al. (2011) analyzed 141 pesticide residues in 31 orange samples from the local markets in Cairo; 22 (66.7\%) of them were contaminated with 8 different pesticide residues, including fenpropathrin and chlorpyrifos, which were also detected in this work.

Knezevic et al. (2012) studied 103 pesticides (including isomers) in 105 commercial orange samples in Croatia from 2007 to 2009 and diazinon residues were found up to levels of $0.28 \mathrm{mg} \cdot \mathrm{kg}^{-1}$.

The United Stated Department of Agriculture Pesticide (USDA) Pesticide Data Program (PDP) analyzed pesticides in 744 orange samples from test year 2010. This monitoring program recorded the presence of chlorpyrifos $(0,7 \%)$ and azoxystrobin $(0,7 \%)$ also investigated in this work. (United States Department of Agriculture, 2012).

The assessment of the estimated chronic risk from orange intake is indicated in Table 3. The health risk characterization, based on the mean and highest results found in this work, respectively ranged from 0.04 to $0.37 \%$ and from 0.13 to $6.62 \%$ of the ADI for adults and from 0.14 to $1.46 \%$ and from 0.54 to $26.5 \%$ of the ADI for children.

Dietary exposure to pesticides is of health concern due to the potentially toxic effects. Vulnerable groups such as the elderly, diabetics, or pregnant women may be more susceptible to pesticides (Juraske et al., 2009). Children are much more sensitive to the toxicity of contaminants than adults are because of their lower body weight and active developmental processes (Au, 2002).

Health effects of pesticides may be increased by fruit and vegetable consumption, which is promoted in many countries. Fresh fruits are a vulnerable part of the diet because they are generally consumed raw, semi-processed, or directly after picking (Parveen et al., 2011). According to the World Health Organization (WHO), orange consumption accounts for an average of $21 \%$ of the estimated diets of Latin America and European communities (World Health Organization, 2003). In Brazil, the consumption of fruits increased by 17.9\% between 2002 and 2009 (Instituto Brasileiro de Geografia e Estatística, 2010), highlighting the importance of evaluating the risk characterization for whole oranges and related products.

Thus, ensuring the quality and safety food is necessary to prevent increased health risks from the consumption of food containing pesticide residues. Monitoring programs for detection of pesticide residues in food should provide improved health risk estimates for sanitary actions in order to minimize the presence of and exposure to pesticide residue, especially non-authorized pesticides.
Herein, pesticide residues in orange samples from São Paulo City were assayed, and assessment of the estimated chronic risk due to orange intake was undertaken as a contribution to the database for characterization of risk due to food intake. Further studies of pesticide residue levels in a wider range of basic foods are required in order to protect consumers from the associated health risks.

\section{Conclusions}

The detection of pesticide residues of unauthorized substances and pesticides at concentrations above the MRL indicates the need for the enforcement of Good Agricultural Practices and better control of product formulations in trade and agriculture, and emphasizes the need for continuous pesticide residue monitoring programs. Based on the mean pesticide residues found in the assessment of the estimated chronic risk for adult and infant populations due orange consumption in this study, the pesticides are ranked in order of descending risk as follows: parathion, fenitrothion, profenofos, myclobutanil, bifenthrin, clofentezine, and azinphos-ethyl. The other investigated pesticide residues do not represent a health risk to the population of São Paulo City due to orange intake.

\section{Acknowledgements}

We thank Antonia Silva Lima and Maria Silvia de Lima Taga for their technical support with the analyses.

\section{References}

Anastassiades, M., Lehotay, S. J., Štajnbaher, D., \& Schenck, F. J. (2003). Fast and easy multiresidue method employing acetonitrile extraction/partitioning and "dispersive solid-phase extraction" for determination of pesticide residue in produce. Journal of AOAC International, 86(2), 412-431. PMid:12723926.

Agência Nacional de Vigilância Sanitária - ANVISA. (2008). Agrotóxicos e toxicologia: Programa de Análise de Resíduos de Agrotóxicos em Alimentos (PARA) (Relatório de Atividades de 2001-2007). Brasília: ANVISA. Retrieved from http://portal.anvisa.gov.br/wps/ content/Anvisa+Portal/Anvisa/Inicio/Agrotoxicos+e+Toxicologia/ Assuntos+de+Interesse/Programa+de+Analise+de+Residuos+de+ Agrotoxicos+em+Alimentos

Agência Nacional de Vigilância Sanitária - ANVISA. (2009). Agrotóxicos e toxicologia: Programa de Análise de Resíduos de Agrotóxicos em Alimentos (PARA) (Nota Técnica para divulgação dos resultados 2008). Brasília: ANVISA. Retrieved from http://portal.anvisa.gov.br/wps/ content/Anvisa+Portal/Anvisa/Inicio/Agrotoxicos+e+Toxicologia/ Assuntos+de+Interesse/Programa+de+Analise+de+Residuos+de+ Agrotoxicos+em+Alimentos

Agência Nacional de Vigilância Sanitária - ANVISA. (2010). Agrotóxicos e toxicologia. Programa de Análise de Resíduos de Agrotóxicos em Alimentos (PARA) (Relatório do PARA 2009). Brasília: ANVISA. Retrieved from http://portal.anvisa.gov.br/wps/content/Anvisa+Portal/ Anvisa/Inicio/Agrotoxicos+e+Toxicologia/Assuntos+de+Interesse/Pr ograma+de+Analise+de+Residuos+de+Agrotoxicos+em+Alimentos

Agência Nacional de Vigilância Sanitária - ANVISA. (2011). Programa de Análise de Resíduos de Agrotóxicos em Alimentos (PARA) (Relatório de Atividades de 2010). Brasília: ANVISA. Retrieved from http:// portal.anvisa.gov.br/wps/content/Anvisa+Portal/Anvisa/Inicio/ 
Agrotoxicos+e+Toxicologia/Assuntos $+\mathrm{de}+$ Interesse/Programa $+\mathrm{d}$ $\mathrm{e}+$ Analise $+\mathrm{de}+$ Residuos $+\mathrm{de}+$ Agrotoxicos+em+Alimentos

Agência Nacional de Vigilância Sanitária - ANVISA. (2012). Índice das monografias dos ingredientes ativos de agrotóxicos, domissanitários e preservantes de madeira. Retrieved from http://portal.anvisa.gov.br/ wps/content/Anvisa+Portal/Anvisa/Inicio/Agrotoxicos+e+Toxicologia/ Assuntos+de+Interesse/Monografias+de+Agrotoxicos

Agência Nacional de Vigilância Sanitária - ANVISA. (2013). Programa de Análise de Resíduos de Agrotóxicos em Alimentos (PARA) (Relatório de Atividades de 2011 e 2012). Brasília: ANVISA. Retrieved from http://portal.anvisa.gov.br/wps/content/Anvisa+Portal/Anvisa/ Inicio/Agrotoxicos+e+Toxicologia/Assuntos+de+Interesse/Progr ama+de+Analise+de+Residuos+de+Agrotoxicos + em + Alimentos

$\mathrm{Au}, \mathrm{W}$. W. (2002). Susceptibility of children to environmental toxic substances. International Journal of Hygiene and Environmental Health, 205(6), 501-503. http://dx.doi.org/10.1078/1438-463900179. PMid:12455272.

Barros, H. R. M., Ferreira, T. A. P. C., \& Genovese, M. I. (2012). Antioxidant capacity and mineral content of pulp and peel from commercial cultivars of citrus from Brazil. Food Chemistry, 134(4), 1892-1898. http://dx.doi.org/10.1016/j.foodchem.2012.03.090. PMid:23442635.

Bempah, C. K., Buah-Kwofie, A., Denutsui, D., Asomaning, J., \& Tutu, A. O. (2011). Monitoring of pesticide residues in fruits and vegetables and related health risk assessment in Kumasi Metropolis, Ghana. Research Journal of Environmental and Earth Sciences, 3(6), 761-771.

Brasil. Ministério da Agricultura, Pecuária e Abastecimento. (2015). Citrus. Brasília: MAPA. Retrieved from http://www.agricultura.gov. br/vegetal/culturas/citrus.

Brasil. Ministério da Saúde. Agência Nacional de Vigilância Sanitária. (2003, September 2). Determina a publicação do "índice das monografias dos ingredientes ativos de agrotóxicos, domissanitários e preservantes de madeira" (Resolução RE n 165 , de 2 de setembro de 2003). Diário Oficial [da] República Federativa do Brasil.

Brasil. Ministério da Saúde. Agência Nacional de Vigilância Sanitária. (2014, August 5). Cancelamento do ingrediente ativo endossulfam (Resolução RE no 2908, de 5 de agosto de 2014). Diário Oficial [da] República Federativa do Brasil. Retrieved from http://portal. anvisa.gov.br/wps/wcm/connect/45fefa004547a5be8ba1dbabe9 7facla/CANCELAMENTO+MONOGRAFIA+DOU+06-08-14. pdf?MOD=AJPERES

Campos, F. J., \& Omoto, C. (2002). Resistance to hexythiazox in Brevipalpus phoenicis (Acari: Tenuipalpidae) from Brazilian citrus. Experimental \& Applied Acarology, 26(3-4), 243-251. http://dx.doi. org/10.1023/A:1021103209193. PMid:12537296.

Chen, C., Qian, Y., Chen, Q., Tao, C., Li, C., \& Li, Y. (2011). Evaluation of pesticide residues in fruits and vegetables from Xiamen, China. Food Control, 22(7), 1114-1120. http://dx.doi.org/10.1016/j. foodcont.2011.01.007.

Codex Alimentarius. (1999). Recommended methods of sampling for the determination of pesticide residues for compliance with MRLs: CAC/ GL 33. Codex Committee on Pesticide Residues. Retrieved from http://www.codexalimentarius.org/standards/list-of-standards/en/

European Commission - EC. (2009). Environmental fate, ecotoxicology, and human health. Azinphos-ethyl (EC Directive 1107/2009). Brussels: EC. Retrieved from http://sitem.herts.ac.uk/aeru/ppdb/ en/Reports/51.htm

European Commission - EC. (2013). Guidance document on analytical quality control and validation procedures for pesticide residues analysis in food and feed (42 p., SANCO/12571/2013). Brussels: EC. Retrieved from http://ec.europa.eu/food/plant/pesticides/guidance_documents/ docs/qualcontrol_en.pdf

European Food Safety Authority - EFSA. (2010). Annual report on pesticide residues. EFSA Journal, 8(6), 1646.

Fallico, B., D’urso, M. G., \& Chiappara, E. (2009). Exposure to pesticides residues from consumption of Italian blood oranges. Food Additives and Contaminants, 26(7), 1024-1032. http://dx.doi. org/10.1080/02652030902839731. PMid:19680977.

Farag, R. S., Abdel Latif, M. S., Abd El-Gawad, A. E., \& Dogheim, S. M. (2011). Monitoring of pesticide residues in some Egyptian herbs, fruits and vegetables. International Food Research Journal, 18, 659-665.

Food and Agriculture Organization - FAO. World Health Organization - WHO. (2005). Fruit and vegetables for health. In Report of a Joint FAO/WHO Workshop, Kobe, Japan. Retrieved from http://www.who. int/dietphysicalactivity/publications/fruit_vegetables_report.pdf

Food and Agriculture Organization - FAO. (2008). FAOSTAT: Food and Agriculture Organization corporate statistical database. Rome: FAO. Retrieved from http://www.fao.org/corp/statistics/en/

Gebara, A. M., Ciscato, C. H. P., \& Monteiro, S. H. (2008). Pesticide residues evaluation in fruit samples commercialized in São Paulo City, Brazil, 2002-2005. Revista Brasileira de Toxicologia, 21(2), 87-92.

Groppo, V.D., Spoto, M.H.F., Gallo, C.R., \& Sarmento, S.W.B.S. (2009). Efeito do cloreto de cálcio e da película de alginato de sódio na conservação de laranja 'Pera' minimamente processada. Ciencia \& Tecnologia de Alimentos, 29(1), 107-113.

Hjorth, K., Johansen, K., Holen, B., Andersson, A., Christensen, H. B., Siivinen, K., \& Toome, M. (2011). Pesticide residues in fruits and vegetables from South America: a Nordic project. Food Control, 22(11), 1701-1706. http://dx.doi.org/10.1016/j.foodcont.2010.05.017.

Iñigo-nuñez, S., Herreros, M. A., Encinas, T., \& Gonzalez-Bulnes, A. (2010). Estimated daily intake of pesticides and xenoestrogenic exposure by fruit consumption in the female population from a Mediterranean country (Spain). Food Control, 21(4), 471-477. http:// dx.doi.org/10.1016/j.foodcont.2009.07.009.

Instituto Brasileiro de Geografia e Estatística - IBGE. (2010). Pesquisa de orçamentos familiares (POF 2008-2009): aquisição alimentar domiciliar per capita. Rio de Janeiro: IBGE. Retrieved from www.ibge. gov.br/home/estatistica/população/condicaodevida/pof/2008_2009/ POFpublicação.pdf

Instituto Brasileiro de Geografia e Estatística - IBGE. (2015). Levantamento sistemático de produção agrícola (LSPA): dados de previsão de safra, produção: Brasil - Janeiro 2015. Rio de Janeiro: IBGE. Retrieved from http://www.sidra.ibge.gov.br/bda/prevsaf/default.asp

Instituto Brasileiro do Meio Ambiente e dos Recursos Naturais Renováveis - IBAMA. (2014). Boletim anual de produção, importação, exportação e vendas de agrotóxicos no Brasil. Brasília: IBAMA. Retrieved from http://www.ibama.gov.br/areas-tematicas-qa/relatorios-decomercializacao-de-agrotoxicos/pagina-3

Jardim, A. N. O., \& Caldas, E. D. (2012). Brazilian monitoring programs for pesticide residues in food: results from 2001 to 2010. Food Control, 25(2), 607-616. http://dx.doi.org/10.1016/j.foodcont.2011.11.001.

Jensen, B., Petersen, A., \& Christensen, T. (2009). Probabilistic assessment of the cumulative dietary acute exposure of the population of Denmark to organo-phosphorus and carbamate pesticides. Food Addit Contam Part A, 26, 1038-1048.

Juraske, R., Mutel, C. L., Stoessel, F., \& Hellweg, S. (2009). Life cycle human toxicity assessment of pesticides: Comparing fruit and vegetable diets in Switzerland and the United States. Chemosphere, 77(7), 939-945. http://dx.doi.org/10.1016/j.chemosphere.2009.08.006. PMid:19729188. 
Knezevic, Z., Serdar, M., \& Ahel, M. (2012). Risk assessment of the intake of pesticides in Croatian diet. Food Control, 23(1), 59-65. http://dx.doi.org/10.1016/j.foodcont.2011.06.011.

Neff, R. A., Hartle, J. C., Laestadius, L. I., Dolan, K., Rosenthal, A. C., \& Nachman, K. E. (2012). A comparative study of allowable pesticide residue levels in produce in the United States. Globalization and Health, 8(2), 1-14. Retrieved from http://www.globalizationandhealth. com/content $/ 8 / 1 / 2$

Parveen, Z., Riazuddin, I. S., Khuhro, M. I., Bhutto, M. A., \& Ahmed, M. (2011). Monitoring of multiple pesticide residues in some fruits in Karachi, Pakistan. Pakistan Journal of Botany, 43, 1915-1918.

Rogers, M. E., \& Dewdney, M. M. (2012). Florida citrus pest management guide: Pesticide resistance and resistance management. Gainesville: University of Florida. Retrieved from http://edis.ifas.ufl.edu/cg026

The Netherlands. (1996). Analytical methods for pesticides in foodstuffs (6th ed.). General Inspectorate for Health Protection, Duty Ministry of Public Health, Welfare and Sports.

Toledo, H. H. B., Rocha, S. B., Kussumi, T. A., \& Lemes, V. R. R. (2005). Resíduos de pesticidas, 370/IV método multi-resíduo para determinação de pesticidas em frutas e vegetais. In: O. Zenebon \& N. S. Pascuet (Coords.), Métodos físico-químicos para análise de alimentos (chap. 20, pp. 687-694). Brasília: ANVISA.

Torres, C. M., Picó, Y., Redondo, M. J., \& Mañes, J. (1996). Matrix solidphase dispersion extraction procedure for multiresidue pesticide analysis in oranges. Journal of Chromatography A, 719(1), 95-103. http://dx.doi.org/10.1016/0021-9673(95)00467-X. PMid:8589838.

United States Department of Agriculture - USDA. (2012). Pesticide data program: annual summary, calendar year 2010. Washington, DC: USDA. Retrieved from http://www.ams.usda.gov/sites/default/ files/media/2010\%20PDP\%20Annual\%20Summary.pdf

United States Environmental Protection Agency - USEPA. (2014). Mosquito control malathion. Washington, DC: USEPA. Retrieved from http://www2.epa.gov/mosquitocontrol/malathion

World Health Organization - WHO. (2003). Global environmental monitoring/food contamination monitoring and assessment programme (GEMS/Food): regional diets (regional per capita consumption of raw and semi-processed agricultural commodities). Geneva: WHO. Retrieved from http://www.who.int/foodsafety/chem/gems_regional_diet.pdf 